\title{
11. A különleges jogrend az Egyesült Királyságban
}

DOMANICZKY ENDRE

\section{A különleges jogrend alkotmányos és törvényi szintú szabályozása}

Az Egyesült Királyságban a különleges jogrenddel kapcsolatos szabályok törvényi szinten kerültek megalkotásra. Maga a szabályozási igény történetileg korán, már a kora újkorban jelentkezett, de a hatályos joganyag közvetlen előzménye a 20. század eleji jogszabályok között lelhetô fel. ${ }^{1}$

Az Egyesült Királyság² krízismenedzsmentje alapvetően egyetlen jogszabályra épül, ez pedig a 2004-es, a nem katonai jellegú rendkívüli eseményekról szóló törvény. ${ }^{3}$ Ennek megalkotásával egyrészt a korábban különböző jogszabályokban szétszórtan található szabályok egységesítésre és modernizálásra kerültek, másrészt az egységes törvény elfogadása által számos, korábban a common law-ban található hatáskör került át az írott jog (statute law) területére. ${ }^{4}$

1 Vö. többek között: Defence of the Realm Act (1914), Emergency Powers Act (1920), Emergency Powers Act (Northern Ireland) (1926), Emergency Powers (Defence) Act (1939), Emergency Powers Act (1964). Lásd még: Bowman, 1916; Cotter 1953; Rosenfeld-Sajó, 2013.

2 A többi angolszász ország szabályozására lásd:Vikman, 2020, 259-279. o.

3 Civil Contingencies Act (a továbbiakban: CCA). (Megjegyzendő, hogy a hazai szakirodalom a jogszabályt többnyire polgári vészhelyzeti törvényként fordítja.).

4 UK Cabinet Manual 3.33-3.38. pontok. Elérhető: https:/assets.publishing.service.gov.uk/government/ uploads/system/uploads/attachment_data/file/60641/cabinet-manual.pdf (Letöltve: 2020. november 18.).

Dr. Domaniczky Endre, PhD

endre.domaniczky@mfi.gov.hu

vezető kutató (Mádl Ferenc Összehasonlító Jogi Intézet)

Domaniczky, E. (2021) 'A különleges jogrend az Egyesült Királyságban' in Nagy, Z., Horváth, A. (szerk.) A különleges jogrend és nemzeti szabályozási modelljei, 252-276. o. Budapest: Mádl Ferenc Összehasonlító Jogi Intézet.

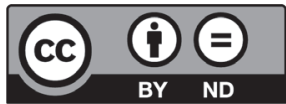


A törvény elnevezése furcsának tû́nhet, de ha egy pillantást vetünk a hasonló európai jogszabályok kodifikációs megoldásaira, ${ }^{5}$ akkor egyértelmúvé válik az angol megoldás modellszerüsége. A kivételes hatalom a hatalom birtokosának oldaláról nézve katonai vagy polgári hatóságok által gyakorolt lehet. A 19. századi korai kodifikációk során az elóbbi modell mellett döntött például a német vagy francia jogalkotó, az utóbbi mellett pedig a brit és a magyar. ACCA elnevezése - a nem katonai, vagyis polgári jellegú eseményekre vonatkozó szabályozás e jogtörténeti előzmények ismeretében válik egyértelmúvé, hiszen a törvény már a címében is utal rá, hogy az irányítás a rendkívüli helyzetben is a polgári hatóságok kezében marad.

A szerkezetileg három részre tagolt CCA egységes szabályozást biztosít a felkészülésre, a tervezésre, a védekezésre (első rész, 1-18. \$), valamint rögzíti a különleges jogrend bevezetésének feltételeit és korlátait (második rész, 19-31. \$). ${ }^{6}$ A törvény elsősorban keretszabályokat ír elö, az eljárási szabályokat rendeletek (regulations, illetve orders) tartalmazzák. ${ }^{7}$ Kiemelt szerepe van továbbá a körleveleknek, tájékoztatóknak, útmutatóknak és megállapodásoknak is, amelyek a felkészülésben segítik az egyes szervezeteket. Bár ez utóbbi szabályozóknak csak egy része rendelkezik jogi kötőerővel, rendszeresen hivatkozzák őket. ${ }^{8}$

A CCA az eljárásra kötelezett szervezetek két fajtáját különbözteti meg, ezekre már békeidőben is különböző feladatok és kötelezettségek hárulnak. Az első és második kategóriás szervezetek körét a törvény mellékletei többnyire országrészekre (Anglia, Skócia, Wales, Észak-Írország) lebontva határozzák meg.

Első kategóriás szervezetek a helyi önkormányzatok, az egészségügyi szolgáltató szervek, a katasztrófavédelmi szervezet, egyéb, a törvény által megnevezett szervek. Második kategóriás szervezetek például a közszolgáltatók (víz, energia, szennyvíz) és a közlekedési szolgáltatók (busz- és vasúttársaságok, repülőterek, autópálya-ügynökségek, kikötői hatóságok). ${ }^{9} \mathrm{Az}$ első körbe tartozó szervezetek legfontosabb feladata az elhárítás és védekezés területén való közremúködés. A második kategóriába tartozó szervezetek az úgynevezett együttmúködő szervezetek, amelyeket a tervezésbe kevésbé szükséges bevonni, viszont váratlan esemény bekövetkezése esetén könnyen érintetté válhatnak, ezért az együttmúködési és információáramlási csatornákat feléjük és közöttük ki kell építeni és fenn kell tartani.

A különleges jogrendet megelőző, az arra való felkészülést segítő békeidejú szabályok többsége az első kategóriás szervezetekre vonatkozik. Ezek legfontosabb feladata a veszélyhelyzeti tervek elkészítése, kockázatbecslés, veszélyhelyzeti tervek hatálybaléptetése,

5 Erről bővebben lásd jelen kötet 5. fejezetét.

6 A CCA harmadik része kiegészító és magyarázó rendelkezéseket tartalmaz (32-36. \$).

7 A legfontosabbak ezek közül: a Civil Contingencies Act (2004), (Contingency Planning) Regulations (2005), illetve két, 2011-es (Civil Contingencies Act 2004 [Contingency Planning] [Amendment] Regulations 2011) és 2012-es módosítása (Civil Contingencies Act 2004 [Contingency Planning] [Amendment] Regulations 2013), amelyek a vészhelyzeti tervezés részletszabályait tartalmazzák.

8 Ezek elsősorban a kormányzati oldalon találhatóak, lásd például: www.gov.uk/guidance/preparation-andplanning-for-emergencies-responsibilities-of-responder-agencies-and-others (Letöltve: 2020. január 13.).

9 Vö.: CCA 1. melléklet 3. rész 1. kategória, 19-28. pontok. 
a vállalkozások zavartalan múködéséhez szükséges intézkedések megtétele, a lakosság tájékoztatása érdekében szükséges teendők megtétele, a különböző helyi szervezetek közti információáramlás segítése a koordináció növelése érdekében, a vállalkozások tájékoztatása - és azok felkészítése - a vállalkozások múködésének biztosítását lehetôvé tevő tervről. ${ }^{10}$

A központi kormányzaton belüli koordinációs szerv ${ }^{11}$ a miniszterelnökségen belül található Civil Contingencies Secretariat, ${ }^{12}$ ide nemcsak vertikálisan, de horizontálisan, az ügygazda minisztériumoktól és ügynökségektôl is érkeznek információk..$^{13}$

A CCA-t a brit gyakorlat afféle végső eszköznek tekinti, alkalmazására 2004-es elfogadása óta még nem került sor. ${ }^{14} \mathrm{~A}$ legújabb jogfejlődési irány a CCA „végsőeszköz-jellegét” látszik megerősíteni, ugyanis 2020 elején a vírusjárvány kezeléséhez a jogszabály élesítése helyett külön speciális törvény (koronavírus-törvény, továbbiakban: $\mathrm{CVA})^{15}$ megalkotására került sor.

Bár a különböző méretû́ katasztrófák kezelése - azok jellege és súlyossága szerint - több törvény, így különösen a koronavírus-törvény és egyes ágazati törvények alkalmazásával is lehetséges, a különleges jogrend bevezetésére csak a CCA alapján kerülhet sor (a konkrét alkalmazási szabályokat lásd lentebb, a fejezet 2. pontjában).

Azt már nagyjából másfél évszázaddal korábban találóan megállapította Concha Győző, hogy „Angliában [...] az alkotmány nem egy törvénynek vagy egyes főtörvényeknek egyenes teremtménye, hanem az összes, évszázadokon keresztül alkotott parlamenti végzemények, a százados nemzeti közszokás visszfénye [...] ${ }^{16} \mathrm{Az}$ Egyesült Királyságban az alkotmányos alaptörvények listája nincs tehát kőbe vésve, viszont éppen a kivételes hatalommal való esetleges

10 Vö. például a kormányzati tájékoztató oldal anyagait. Elérhető: www.gov.uk/guidance/preparation-andplanning-for-emergencies-responsibilities-of-responder-agencies-and-others (Letöltve: 2020. január 13.).

11 Súlyosabb (2-3. szint) krízishelyzetben viszont a központi válságkezelő szerv a Kabinet Döntéshozó Irodái elnevezésú formáció, a szakszövegekben COBR-ként, a sajtóban viszont gyakran COBRA-ként hivatkozott Cabinet Office Briefing Rooms. Szerepére lásd: https://assets.publishing.service.gov.uk/government/uploads/ system/uploads/attachment_data/file/192425/CONOPs_incl_revised_chapter_24_Apr-13.pdf (különösen 2141. oldal). (Letöltve: 2020. január 13.) A krízishelyzetszinteket lásd: https://assets.publishing.service.gov.uk/ government/uploads/system/uploads/attachment_data/file/192425/CONOPs_incl_revised_chapter_24_Apr13.pdf, különösen 68. oldal. (Letöltve: 2020. január 13.).

12 Lásd a Civil Contingencies Secretariat (CCS) honlapját: www.gov.uk/government/emergency-preparationreponse-and-recovery. 2019 elején a részleg 94 fös személyzettel rendelkezett. Lásd még: https:// researchbriefings.parliament.uk/ResearchBriefing/Summary/LLN-2019-0034 (Letöltve: 2019. december 17.).

13 Központi szinten az elsődlegesen érintett kormányzati szervek a miniszterelnökség (Cabinet Office), a belügyminisztérium (Home Office), az önkormányzati minisztérium (Ministry of Housing, Communities and Local Governments), a védelmi minisztérium (Ministry of Defence), az egészségügyi és szociális minisztérium (Department of Health and Social Care). Elérhető: www.gov.uk/government/emergency-preparation-reponse-andrecovery\#guidance_and_regulation (Letöltve: 2020. január 13.).

$14 \mathrm{Ez}$ a megfontolt jogalkalmazási gyakorlat egyáltalán nem egyedülálló jelenség a brit jogtörténetben. A CCA előzményeként szolgáló 1920-as különleges jogrendi törvényt (Emergency Powers Act) 84 év alatt mindössze 12 alkalommal alkalmazták. Vö.: www.instituteforgovernment.org.uk/explainers/emergencypowers (Letöltve: 2020. június 19.).

15 Skóciában külön koronavírus-törvényt fogadtak el, ez a Coronavirus (Scotland) Act 2020 (a továbbiakban: CVAS).

16 Concha, 1888, II/177. o. 
visszaélés miatt a CCA tervezetének vitája során felmerült egy tételes lista meghatározása, és abban mind a különleges jogrendről szóló akkor hatályos, mind pedig az akkor tárgyalás alatt lévő, jelenleg hatályos törvény említésre került. ${ }^{17}$ Miután a CCA-t az elfogadása óta eltelt másfél évtizedben még nem alkalmazták, a probléma egyelőre csak elméleti szintű, de ez a közel két évtizedes vita jól jelzi a szabályozási tárgykör alkotmányos súlyát és helyzetét.

A téma szempontjából releváns törvények általában nem értelmezhetők önmagukban, a részletszabályokat különböző formában hozott rendeletek ${ }^{18}$ (statutory instruments) tartalmazzák. A CCA végrehajtási rendeletei tárgyuk szerint négy csoportba oszthatók:

- a CCA hatálybalépésével kapcsolatos végrehajtási rendeletek: a három rendelet a korábbi veszélyhelyzeti szabályozás és az új törvény harmonizációját végezte el, elsősorban a korábbi törvények hatályon kívül helyezésével;

- a veszélyhelyzetre való felkészülés (vészhelyzeti tervezés) részletszabályai és ezek módosításai: a vészhelyzeti tervezés szabályainak meghatározása az egyes országrészekre, egyes feladatoknál szabályozási jogkörök biztosítása, adatkezelési és adattovábbítási szabályok elöírása;

- a CCA első részéhez kapcsolódó első és második kategóriás szervezetek körének módosítása: a törvény ezen részei rendeleti úton módosíthatók;

- a törvény Skóciában való alkalmazását biztosító rendeletek: Skócia az Egyesült Királyság egyik, széles autonómiával bíró országrésze, ahol egyes szabályok önálló megalkotása vagy külön keretszabályozás kialakítása lehet szükséges. A CCA esetében eddig a törvény hatálybalépésének és a vészhelyzeti tervezésnek az ügyében készült önálló szabályozás.

\section{A különleges jogrend esetkörei}

\subsection{Fogalom és elöfeltételek}

A CCA-ban a szabályozási tárgyra vonatkozó egy évszázados kodifikációs tapasztalat sûrűsödik össze. A törvény második része - mint egy „míves lakat” - kiemelt védelemben

17 Vö.: Joint Committee on Draft Civil Contingencies Bill First Report 183. pont. Elérhető: https://publications. parliament.uk/pa/jt200203/jtselect/jtdcc/184/18407.htm\#a44, 183. pont (Letöltve: 2020. december 1.).

18 Ezek a következők: The Civil Contingencies Act 2004 (Commencement No.1) Order 2004; The Civil Contingencies Act 2004 (Commencement No.2) Order 2005; The Civil Contingencies Act 2004 (Commencement No.3) Order 2005; The Civil Contingencies Act 2004 (Contingency Planning) Regulations 2005; The Civil Contingencies Act 2004 (Contingency Planning) (Amendment) Regulations 2011; The Civil Contingencies Act 2004 (Contingency Planning) (Amendment) Regulations 2012; The Civil Contingencies Act 2004 (Amendment of List of Responders) Order 2005; The Civil Contingencies Act 2004 (Amendment of List of Responders) Order 2008; The Civil Contingencies Act 2004 (Commencement) (Scotland) Order 2005; The Civil Contingencies Act 2004 (Contingency Planning) (Scotland) Regulations 2005; The Civil Contingencies Act 2004 (Contingency Planning) (Scotland) Amendment Regulations 2013. Részletesen lásd: www.legislation.gov.uk. 
részesíti a különleges jogrend bevezetését lehetővé tevő kivételes hatalmat. A hatalom mindenkori birtokosai számára a CCA csak egy bonyolult feltételrendszer teljesülése esetén teszi lehetôvé a kivételes hatalom gyakorlását. Ahhoz, hogy a kodifikátori teljesítményt értékelni tudjuk, a legfontosabb rendelkezéseket előbb át kell tekintenünk.

A CCA egyetlen kivételes hatalom gyakorlását lehetővé tevő esetkörrel, a szükségállapottal (emergency) dolgozik, és egy hármas feltételrendszer teljesülése esetén teszi lehetővé a kivételes hatalom gyakorlását: ${ }^{19}$

— a szükségállapot bevezetését igénylő esemény megtörtént, éppen most történik vagy bekövetkezése várható;

- az esemény megelőzéséhez, kontrollálásához vagy hatásának enyhítéséhez szabályalkotás szükséges;

— a szabályalkotásra sürgősen van szükség.

Látszólag egyszerủ fogalomról és könnyen meghatározható előfeltételekről van szó, azonban a törvény több esetben ${ }^{20}$ - már az előfeltételeken belül is - él a többszörösen összetett definíciók alkalmazásának lehetőségével. Ennek megfelelően a fenti értelmező rendelkezésben szereplő szükségállapot fogalmát a CCA külön is - alapvetően tágan - megadja. ${ }^{21}$

Szükségállapotnak minősül:

— amely az Egyesült Királyság területén a közjólétet súlyosan károsító esemény vagy helyzet bekövetkezésével fenyeget;

— amely az Egyesült Királyság területén belül a környezetet súlyosan károsító esemény vagy helyzet bekövetkezésével fenyeget;

- háború, terrorcselekmény, amely az Egyesült Királyság biztonságának súlyos károsodásával fenyeget.

Ezen túlmenően a CCA a szükségállapot-fogalmon belüli egyes szavak értelmezésére is vállalkozik, ezzel azonban inkább bővíti, mint szúkíti a szükségállapot-fogalom alkalmazhatóságát. Így például a törvény szerint közjólétet károsító esemény vagy helyzet az, amely emberi élet kioltásával, emberi megbetegedéssel vagy sérüléssel, földönfutóvá válással, a tulajdon károsodásával; a pénz-, az élelem-, a víz-, az energia- vagy üzemanyag-szolgáltatás fennakadásával; a kommunikációs rendszer, a közlekedési lehetőségek, az egészségügyi szolgáltatások megszakadásával jár vagy járhat. ${ }^{22}$ Környezeti kár bekövetkezésével fenyegető esemény vagy helyzet pedig lehet a talaj, a víz, a levegó biológiai, kémiai, radioaktív anyaggal való szennyezése vagy annak előidézése, a növény- vagy állatvilág elpusztítása, illetőleg károsodásának előidézése. ${ }^{23}$

19 Vö.: CCA 21. \$ (2)-(4) bekezdés.

20 Vö.: CCA 19. $\$(2)$ bekezdés.

21 Vö.: CCA 1. \$ (1)-(3) bekezdés.

22 Vö.: CCA 19. \$ (2) bekezdés.

23 Vö.: CCA 19. \$ (3) bekezdés. 


\subsection{A kivételes hatalom}

Amennyiben az előfeltételek fennállnak, és a törvény hozzáférést enged a kivételes hatalomhoz, azonnal láthatóvá válik, hogy bár a hatalomgyakorlás normális menetéhez képest széles körü, és ezért kivételes hatalomról van szó, annak gyakorlása mégsem korlátlan. Sőt a CCA - a második részben - maga rögzíti a kivételes hatalom korlátait, korlátok közé szorítva ezáltal a kivételes hatalom gyakorlásán alapuló jogrend, a különleges jogrend jogforrásait is.

A kivételes hatalom korlátai a következők:

- korlátozott tárgyi hatály;

— korlátozott időbeli hatály;

- parlamenti kontroll.

Mielőtt azonban a korlátokat megvizsgálnánk, szót kell ejteni a végrehajtó hatalom mindenkori birtokosairól, akik a CCA alapján a kivételes hatalom gyakorlására jogosultak. A törvény a hatalomgyakorlók két csoportját ruházza fel - meghatározott sorrendben - a kivételes hatalom időszakában történő normaalkotásra. ${ }^{24}$ Mindenekelőtt az államfót, aki (szükség)rendeletet (Order-in-Council) ${ }^{25}$ alkothat, amennyiben a CCA 21. \$-ában leírt feltételek fennállnak. ${ }^{26}$ Másodsorban a miniszterek egy meghatározott körét, amennyiben a CCA 21. \$-ában leírt feltételek fennállnak, és a Queens-in-Council formában történő rendeletalkotás jelentős késedelemmel ${ }^{27}$ járna. A miniszterek meghatározott körét a CCA pontosan kibontja:

- a kincstár első lordja, vagyis a brit miniszterelnök;

- bármely államtitkár: ${ }^{28}$ a CCA tervezetéhez készült indokolás rávilágít a tág megfogalmazás keletkezési hátterére, ugyanis a jogalkotó lehetôvé kívánta tenni, hogy a kormányon belül az adott témában illetékes kormánytag minél gyorsabban kaphassa meg a rendeletalkotási felhatalmazást; ${ }^{29}$

- a kincstári megbízottak. ${ }^{30}$

24 Vö.: CCA 20. \$ (1)-(2) bekezdés.

25 A titkos tanácsban történő rendeletalkotásra lásd bővebben: https:/assets.publishing.service.gov.uk/government/ uploads/system/uploads/attachment_data/file/60641/cabinet-manual.pdf(1.14-1.18). (Letöltve:2020. november 19.).

26 A CCA tervezetéhez füzött magyarázatból egyértelmủen kitûnik, hogy a Queens-in-Council formában történő rendeletalkotás az államfő egyes kabinettagokkal történő közös jogalkotására vonatkozik, és ebben az esetben elsősorban a belügyminiszter lenne a jogszabálytervezet elöterjesztője. Vö. a CCA 20. \$ (1) bekezdéséhez füzött magyarázat 42 . pontjával.

27 A ,jelentős késedelem” jelentését a törvény külön meghatározza [CCA 20. \$ (4) bekezdés: „A jelentős késedelem ezen pont alkalmazásában az a késedelem, amely jelentős kárt okoz, vagy a megelőzést, ellenőrzést vagy a jelentős kár enyhítését jelentősen akadályozza."].

$28 \mathrm{Az}$ államtitkár itt miniszteri rangú tisztviselőt jelent. A pontos terminológiára lásd a CCA 20. \$ (3) bekezdés b) pontját és az Interpretation Act 1978 1. mellékletét.

29 Vö. még: a CCA 20. \$ (3) bekezdéséhez füzött magyarázat 43. pontja.

30 Vö. még: a CCA 20. $\$$ (3) bekezdéséhez füzött magyarázat 43. pontja. Elérhető: https://assets.publishing. service.gov.uk/government/uploads/system/uploads/attachment_data/file/60641/cabinet-manual.pdf (3.28-3.29., letöltve: 2020 . november 18.). 
Amennyiben sikerült a jogalkotó személyét meghatározni, e személynek a jogalkotói döntésért való felelősséget jogalkotói nyilatkozat tételével kell vállalnia (jogalkotói előzetes nyilatkozat, a továbbiakban: nyilatkozat). E nyilatkozat - mint az a szabályozásból kiolvasható - egyszerre tölti be a személyes felelősségvállalás, illetve az arányossági teszt szerepét. A nyilatkozat tartalma a következō: ${ }^{31}$

— az adott - szabályozással érintett - szükségállapot jellegének meghatározása;

- a jogalkotó nyilatkozata arra vonatkozóan, hogy:

— meggyőződött a kivételes hatalom gyakorlásához szükséges előfeltételek fennállásáról;

- meggyőződött arról, hogy a (szükség)rendeletek csak olyan rendelkezéseket tartalmaznak, amelyek alkalmasak az adott szükségállapot megelőzésére, ellenőrzésére vagy enyhítésére;

- meggyőződött arról, hogy a (szükség)rendeletek hatása kellően arányos a szükségállapot hatásával vagy jellegével;

— meggyőződött arról, hogy a szabályozás összeegyeztethető az Emberi Jogokról szóló Egyezményben foglalt jogokkal (az emberi jogokról szóló 1998-as törvény 1. szakaszának megfelelően).

Ugyancsak a jogalkotóra hárul az a kötelezettség is, hogy olyan szabályozást alkosson, amelynek alapján, illetve a szabályozásra tekintettel hozott intézkedések alapján a parlament, a legfelsőbb bíróság és a Court of Session ${ }^{32}$ tovább tudjon múködni. ${ }^{33}$

\subsection{Tárgyi és időbeli hatály}

A (szükség)rendeletek - a CCA-t megalkotó brit parlament döntése alapján - nagyon tág, ám mégis korlátozott tárgyi hatállyal rendelkeznek. Ezt kétféle kodifikációs technikával érte el a jogalkotó: általánosan korlátozott tárgyi hatály, illetve speciálisan korlátozott tárgyi hatály meghatározásával.

Bár a kivételes hatalom legfőbb jellemzője éppen a hatalom rendkívüli esetben biztosított „kvázi korlátlansága” lenne, a brit parlament mégis megpróbálta e hatalom jogalkotási tárgyköreit - azok meghatározásával - korlátozni. Ezt egyrészt generális módon, a lehetséges tárgykörök exemplifikatív felsorolásával ${ }^{34}$ éri el. A CCA itt egy listát rögzít (lehetséges

31 Vö.: CCA 20. $\$(5)$ bekezdés.

32 A Court of Session a skót polgárjogi legfelsőbb bíróság elnevezése. Lásd bővebben a skót bírósági honlapon: www. scotcourts.gov.uk/the-courts/supreme-courts/about-the-court-of-session (Letöltve: 2020. november 19.).

33 Vö.: CCA 23. \$ (5) bekezdés.

34 Vö.: CCA 22. \$ (2) bekezdés. 
törvényhozási tárgykörök),, ${ }^{35}$ valamint egy tágan megfogalmazott elöírást, ${ }^{36}$ amely szerint (szükség)rendeletben ezen túlmenően bármilyen rendelkezés elő́rhható, amely egyébként a parlamentben megalkotott törvény vagy királyi előjog gyakorlása által lenne szabályozható. ${ }^{37} \mathrm{~A}$ generális felsorolások mellett a CCA tilalmakat is meghatároz, méghozzá kétféle-

35 A lehetséges törvényhozási tárgykörök a következők:

— az emberi élet, egészség vagy biztonság védelme;

- emberi betegségek vagy sérülések kezelése;

- vagyon védelme vagy helyreállítása;

- pénz-, élelmiszer-, víz-, energia- vagy üzemanyag-ellátás védelme vagy helyreállítása;

- a kommunikációs rendszer védelme vagy helyreállítása;

- a szállításhoz szükséges létesítmények védelme vagy helyreállítása;

- az egészséggel kapcsolatos szolgáltatások nyújtásának védelme vagy helyreállítása;

— bankok vagy más pénzügyi intézmények tevékenységének védelme vagy helyreállítása;

- a talaj, a víz vagy a levegő szennyezésének megelőzése, korlátozása vagy csökkentése;

- a növény- vagy állati élet megzavarásának vagy megsemmisítésének megelőzése, csökkentése vagy enyhítése;

- a parlament, a skót parlament, az észak-írországi közgyúlés vagy a walesi nemzetgyúlés tevékenységeinek védelme vagy helyreállítása;

- a közfeladatok védelme vagy helyreállítása.

36 Vö.: CCA 22. \$ (3) bekezdés

37 A CCA - a jogalkalmazót segítendő - a generális szabályhoz is egy felsorolást kapcsol: a (szükség)rendeletek bármilyen rendelkezést elő́rhatnak, amely a parlamentben megalkotott törvény vagy királyi előjog gyakorlása által lenne elöírható; így különösen:

— a növény- vagy állati élet megzavarásának vagy megsemmisítésének megelőzése, csökkentése vagy enyhítése;

- feladatot ruházhatnak miniszteri rangú tisztviselőkre, a skót miniszterekre, a walesi nemzetgyủlésre, az északír minisztériumra, a CCA 24 . \$-a alapján kinevezett koordinátorra vagy bármely más meghatározott személyre (és az átruházott feladat különösen a következő lehet): hatáskör vagy kötelesség mérlegelési jogkör gyakorlására; hatáskör írásbeli vagy szóbeli utasítások kiadására;

- lehetôvé teheti a tulajdon visszaszolgáltatását vagy elkobzását (kártérítéssel vagy anélkül);

— lehetővé teheti tulajdon, állati vagy növényi élet megsemmisítését (kártérítéssel vagy anélkül);

- megtilthatja a mozgást egy meghatározott helyre vagy helyről;

— kötelezővé teheti a meghatározott helyre vagy onnan történő mozgást;

- megtilthatja a meghatározott típusú gyúlések meghatározott helyeken vagy időpontokban történő megtartását;

- meghatározott időpontokban megtilthatja az utazást;

- megtilthatja egyéb meghatározott tevékenységek végzését;

- büntetendővé teheti: a (szükség)rendeletek valamely rendelkezésének be nem tartását; a (szükség)rendeletek alapján adott utasítás be nem tartását; egy adott személy akadályozása a (szükség)rendelet által elöírt vagy az alapján gyakorolt feladatának ellátásában;

- eltekinthet egy jogszabály vagy a jogszabály alapján hozott rendelkezés alkalmazásától, vagy módosíthatja a jogszabályt vagy az annak alapján hozott rendelkezést;

- megkövetelheti, hogy egy személy vagy testület valamely funkció ellátása érdekében járjon el - függetlenül attól, hogy a funkciót a (szükség)rendeletek ruházzák-e fel vagy sem, és hogy e rendeletek elóírnak-e ezért díjazást vagy kompenzációt;

— lehetővé teheti a védelmi tanács számára, hogy engedélyezze Őfelsége fegyveres erőinek bevetését;

— jogszabályt alkothat (ideértve a tulajdonnal kapcsolatos hatáskörök átruházását) Ôfelsége fegyveres erői bevetésének megkönnyítésére;

— joghatóságot telepíthet egy bíróságra - beleértve a (szükség)rendelet által létrehozott bíróságot is;

- olyan szabályokat alkothat, amelyek a következőkkel kapcsolatban érvényesek: a parti tenger egy része; a brit halászati térségen belüli terület; a kontinentális talapzat területe;

— olyan rendelkezést hozhat, amely vagy általánosan, vagy csak meghatározott körülmények között, vagy csak meghatározott célra alkalmazandó;

— eltérő körülményekre vagy célokra eltérő rendelkezéseket alkothat. 
képpen: általános szabályozási tilalmakat és konkrét törvénymódosítási tilalmakat ír elő. ${ }^{38}$ A CCA által rögzített általános tilalmak a következők:

A (szükség)rendeletek csak akkor bocsáthatók ki, ha és amennyiben a jogalkotó meggyőződött arról, hogy a rendelkezés megfelelő annak a vészhelyzetnek vagy következménynek a megelőzésére, ellenőrzésére vagy enyhítésére, amelyre a szabályozás vonatkozik, és a rendelkezés hatása megfelelő arányban áll a vészhelyzet jellegével vagy hatásával.

A (szükség)rendeletekben meg kell határozni az Egyesült Királyság azon részeit vagy régióit, amelyekre a rendelkezések érvényesek.

A (szükség)rendeletek nem írhatják elő vagy nem adhatnak felhatalmazást annak az előírására, hogy egy személy katonai szolgálatot teljesítsen, illetve nem tilthatják meg vagy nem adhatnak felhatalmazást a sztrájkban vagy más ipari megmozdulásban való részvétel vagy ezzel kapcsolatos bármilyen tevékenység megtiltására.

A (szükség)rendeletek nem állapíthatnak meg - a CCA 22. \$ (3) bekezdés i) pontjában foglaltakat kivéve - búncselekményi tényállást; csak olyan kisebb súlyú büntetőjogi tényállást állapíthatnak meg, amely az alsóbb fokú bíróságok (magistrates' court), ${ }^{39}$ Skóciában a sheriff hatáskörébe (summary process) ${ }^{40}$ tartozik; csak olyan szabálysértési tényállást tartalmazhatnak, amelynek maximális tétele maximum három hónap szabadságvesztés vagy 5. szintnek megfelelő pénzbüntetés; ${ }^{41}$ valamint nem változtathatják meg a büntetőeljárási szabályokat.

Az általános korlátozásokon túlmenően - a kivételes hatalom elé állított speciális jogalkotói korlátozásként - a CCA konkrét törvénymódosítási tilalmakat is tartalmaz, amikor is két törvény, a CCA második része és az emberi jogokról szóló 1998-as törvény (Human Rights Act 1998 - a továbbiakban: HRA) módosítását még szükségállapot esetére is megtiltja. ${ }^{42}$ Azaz a kivételes hatalomról szóló szabályozás - beleértve a kivételes hatalom korlátait is - még szükségállapot idején sem változtatható meg. A második kivétel, a HRA az emberi jogok alapértékjellegére utal. Maga a törvény megemlítése inkább az alapértékek fontosságának hangsúlyozása miatt lehetett fontos a kodifikátorok számára, ugyanis ez a törvény az Emberi Jogok Európai Egyezményének ${ }^{43}$ (EJEE) brit jogrendbe való inkorporálásáról szól. Az EJEE 15. \$-a viszont lehetővé teszi az aláírók számára a szükséghelyzetben történő eltérést.

38 Vö.: CCA 23. \$ (1)-(4) bekezdés.

39 A magistrates' court hatáskörére lásd: www.judiciary.uk/you-and-the-judiciary/going-to-court/magistratescourt (Letöltve: 2020. november 19.).

40 Azok a büntetőügyek, amelyekben a seriff egyedül, esküdtszék nélkül jár el. Bővebben lásd:www.scotcourts. gov.uk/the-courts/sheriff-court/about-sheriff-courts (Letöltve: 2020. november 19.).

41 Ez jelenleg - a Criminal Justice Act 1982 37. \$ (2) bekezdése alapján - 5 ezer fontos pénzbüntetést jelent.

42 Vö.: CCA 23. $\$(5)$ bekezdés.

43 Más néven római egyezmény (Magyarországon becikkelyezte az 1993. évi XXXI. törvény). 
A CCA a kivételes hatalom birtokában megalkotott szabályok időbeli hatályát is korlátozza, ám ezt oly módon teszi, hogy egyúttal világos szabályozási kereteket is biztosít. ${ }^{44}$ A CCA kodifikátorai ugyanis jól érzékelték, hogy a jogbiztonság a jogállam érvényesülésének elengedhetetlen kelléke is, de különösen nagy szükség van rá rendkívüli körülmények között. A tömör, ám mégis részletes szabályok egyik alapvetô célja tehát a jogbiztonság rendkívüli helyzetben történő megőrzése. ${ }^{45}$

A CCA alapján készült (szükség)rendeletek maximum a meghozataluktól 30 napig maradhatnak hatályban. Ez természetesen nem zárja ki a rövidebb ideig tartó hatályt, amenynyiben a rendeletet kibocsátó erre nézve külön rendelkezik. A jogalkotó az alapesethez magyarázatot is fúzött, amelyben egyértelmúen kimondta, hogy a 30 napos korlátozott időbeli hatály egyrészt nem akadályozza új szabályozás megalkotását, másrészt pedig nem vonatkozik a még hatályos (szükség)rendeletek alapján megvalósult intézkedésekre.

\subsection{A kivételes hatalom parlamenti kontrollja}

A kivételes hatalmat korlátozó harmadik elem a parlamenti kontroll, amelyet a CCA - részben az esetleges visszaélések megelőzése érdekében - részletekbe menően szabályoz. ${ }^{46}$

Nincs kibúvó: a (szükség)rendeleteket megalkotásukat követően a brit parlament elé kell terjeszteni, amely dönthet a módosításukról vagy a hatályon kívül helyezésükről is. Az utólagos parlamenti kontroll azonban nem bír halasztó hatállyal: ha a (szükség)rendeletet megalkották, azonnal hatályos, annak alapján a hatóságok eljárhatnak, döntéseik érvényesek, ám a parlament közben a (szükség)rendeletet módosíthatja vagy hatályon kívül helyezheti. ${ }^{47}$ A korábban hatályos rendelet alapján hozott intézkedések érvényességét azonban a parlamenti döntés nem érinti, és a parlamenti ellenőrzés nem akadályozza új (szükség)rendelet alkotását. ${ }^{48}$

A parlament elé terjesztésnek nemcsak eljárási, de a (szükség)rendeletek időbeli hatályát is érintő szabályai vannak. A CCA úgy rendelkezik, hogy a (szükség)rendeleteket a megalkotásukat követô legrövidebb időn belül a parlament elé kell terjeszteni. Ha a parlament a beterjesztéstől számított hét napon belül nem hagyja azokat jóvá, a hetedik nap végén a törvény erejénél fogva hatályukat vesztik. ${ }^{49}$

44 Vö.: CCA 26. \$(1)-(2) bekezdés.

45 Másrészt pontosan egy ilyen kulcsfontosságú probléma, mint az időbeli hatály értelmezésekor válik egyértelművé, hogy a CCA felépítése és megszövegezése - bár elsőre riasztónak hat - valójában nemcsak a jogvégzett, de a laikus személyek általi megértést is próbálja segíteni.

46 Vö.: CCA 27-28. \$.

47 Vö.: CCA 27. \$.

48 Vö.: CCA 27. \$ (4) bekezdés.

49 CCA 27. $\$$ (1) bekezdés b) pont. 
A CCA a parlamenti határozatok joghatásairól is rendelkezik. Ha a parlament egyik háza a (szükség)rendeletek hatályon kívül helyezése mellett foglal állást, akkor azok hatályukat vesztik. ${ }^{50} \mathrm{Ha}$ az ilyen hatályon kívül helyező határozat

- határidőt is tartalmaz, akkor a határozatban foglaltaknak megfelelő időpontban;

- ha a parlamenti határozat nem tartalmaz határidőt, akkor a határozat elfogadását követő nap kezdetén;

- ha a két ház határozatai eltérő napot tartalmaznak, akkor a második határozat meghozatalát követő nap kezdetén

vesztik hatályukat a (szükség)rendeletek.

A CCA a (szükség)rendeletek parlamenti módosítására nézve is tartalmaz szabályokat. ${ }^{51}$ Ha a parlament valamelyik háza úgy határoz, hogy a (szükség)rendelet meghatározott módosítással lép hatályba, akkor ez a módosított verzió lesz majd hatályos:

- ha a határozat tartalmaz időpontot, akkor attól az időponttól;

- ha a határozat nem tartalmaz időpontot, akkor az elfogadást követő nap kezdetétől;

- ha a két ház határozatai eltérố napot tartalmaznak, akkor a második határozat meghozatalát követő nap kezdetétől.

A CCA előrelátó módon a parlamenti ülés elnapolásának, illetve az ülés berekesztésének esetére is tartalmaz rendelkezéseket.

Ha a (szükség)rendeletek megalkotásakor a parlament ülését elnapolták, és ez az állapot a rendeletek megalkotásától számítva öt napnál hosszabb ideig áll fenn, a Meeting of Parliament Act 1797 alapján az uralkodónak egy, az öt napon belüli időpontra a parlamentet össze kell hívnia..$^{52}$

Ha a (szükség)rendeletek megalkotásakor az alsóház ülését berekesztették, és ez az állapot a rendeletek megalkotásától számítva öt napnál hosszabb ideig áll fenn, az alsóház elnökének egy, az öt napon belüli időpontra az alsóház ülését össze kell hívnia. ${ }^{53} \mathrm{Ha}$ a (szükség)rendeletek megalkotásakor a felsőház ülését berekesztették, és ez az állapot a rendeletek megalkotásától számítva öt napnál hosszabb ideig áll fenn, a felsőház elnökének egy, az öt napon belüli időpontra a felsőház ülését össze kell hívnia. ${ }^{54}$

A CCA kodifikátorai még arra is figyelemmel voltak, hogy a szakasz végén egy értelmező rendelkezéssel az alsóház, illetve a felsőház elnökének fogalmát mindazon személyekre ki- 
terjesszék, akik a berekesztés időszakában a házszabályok alapján az alsóház, illetve a felsőház elnöke helyett eljárhatnának. ${ }^{55}$

\subsection{Eljárási szabályok}

A részletekbe menő anyagi jogi szabályozás mellett a CCA kiemelt figyelmet fordít az eljárási szabályok rögzítésére is. Mindenekelőtt rendezi a (szükség)rendeletek jogszabályi hierarchiában elfoglalt helyét, amikor kimondja, hogy a (szükség)rendeleteket rendeleti formában kell megalkotni, és e szabályokat a HRA ${ }^{56}$ szempontjából másodlagos joganyagnak ${ }^{57}$ kell tekinteni. ${ }^{58}$

Bizonyos esetekben a CCA konzultációs kötelezettséget ír elő a kivételes hatalom birtokosa számára. A konzultációt még a jogalkotást megelőzően, az autonómiával felruházott országrészek kormányzatával kell lefolytatni, azonban ez a konzultációs kötelezettség feltételes, vagyis egyes feltételek fennállása esetén mellőzhető.

A törvény alapján, amennyiben a (szükség)rendelet teljes egészében vagy részben Skóciát is érinti, csak a skót minisztertanáccsal való konzultációt követően készíthető el. Az egyeztetést egy vezetô beosztású kormánytagnak kell lefolytatnia, ${ }^{59}$ a lehetséges személyi kört a CCA egy másik helyen pontosan megadja ${ }^{60} \mathrm{~A}$ konzultációra kötelezett kormánytagok közétartozik a kincstár első lordja (vagyis a brit miniszterelnök), bármely államtitkár, valamint a kincstári megbízottak. ${ }^{61}$

Hasonló előzetes konzultációt kell lefolytatni Észak-Írország, illetve Wales kormányzatával még az ezen országrészeket érintő különleges jogrendi jogalkotás megkezdése előtt. Mentesül azonban a konzultációs kötelezettség alól a brit kormány, amennyiben a konzultációra kötelezett személy megítélése szerint erre a sürgős szükség miatt nincs lehetőség. Ilyen esetben a konzultációs kötelezettség elmaradása nem érinti a (szükség)rendelet érvényességét. ${ }^{62}$

Végül az eljárási szabályok között kell megemlékezni a szükséghelyzeti és a regionális koordinátorok kinevezésével kapcsolatos feladatokról. ${ }^{63}$ A kivételes hatalom birtokosának - konkrétan a jogszabály megalkotójának - ugyanis a (szükség)rendelet megalkotásával egyidejưleg szükséghelyzeti koordinátorokat kell kineveznie az Egyesült Királyság mindazon országrészeibe (Anglia kivételével, tehát Skócia, Észak-Írország és Wales), amelyeket a (szükség)rendeleti szabályozás érinteni fog, illetve regionális koordinátorokat kell kineveznie az Egyesült Királyság mindazon régiójába, amelyeket a (szükség)rendeleti sza-

55 CCA 28. $\$$ (4) bekezdés.

56 Vö.: HRA 21. $\$$ (1) bekezdés.

57 Bővebben lásd jelen fejezet 4. pontját.

58 Vö.: CCA 30. \$ (1)-(2) bekezdés.

59 Vö.: CCA 29. \$ (1) bekezdés.

60 Vö.: CCA 31. \$ (1) bekezdés és CCA 20. \$ (3) bekezdés.

61 A kormánytagokra vonatkozóan bővebb magyarázatot és hivatkozásokat lásd jelen fejezet 2.2. pontjában.

62 Vö.: CCA 29. \$ (4) bekezdés.

63 Vö.: CCA 24. \$. 
bályozás érinteni fog. A (szükség)rendeletben rögzíteni kell a szükséghelyzeti, illetve a regionális koordinátorok kinevezésének időtartamát, a munkavégzés körülményeit, valamint a koordinátorok díjazását és a koordinátorok feladatait. ${ }^{64}$

A koordinátorok legfontosabb feladatát a törvény maga szabályozza, amikor kimondja, hogy „a kinevezés elsődleges célja a (szükség)rendeletben foglalt tevékenységek összehangolásának megkönnyítése (akár csak abban az országrészben vagy régióban, ahová a kinevezés szólt, akár részlegesen: részben ott, részben bárhol másutt)". ${ }^{65} \mathrm{~A}$ koordinátornak feladatai ellátása során a vezetô beosztású kormánytag utasításait kell követnie, illetve köteles a vezető beosztású kormánytag útmutatójában foglaltakat betartani. ${ }^{66}$ Másképpen szólva a CCA a fenti szabályozás révén utasítási és útmutató-kibocsátási jogkört biztosít a vezető beosztású kormánytag számára a szükséghelyzeti és a regionális koordinátorok fölött. ${ }^{67}$

\section{Az alapjog-korlátozással kapcsolatos kérdések}

$\mathrm{Az}$ alapjog-korlátozás kérdésének tanulmányozása alapvetően két törvény, a CCA és a CVA vizsgálatát igényli.

A CCA esetében az előző pontban láthattuk, hogy a jogalkotó kiemelt esetként ${ }^{68}$ kezelte az Emberi Jogok Európai Egyezményének való megfelelést, illetve az abban foglalt alapvető jogok szükségállapot idején történő korlátozhatatlanságának biztosítását. Erre utal, hogy a CCA még szükségállapot idején is korlátozhatatlannak minősítette a HRA-t, amely az EJEE rendelkezéseit ültette be a brit jogba. ${ }^{69}$ Itt is szükséges megemlíteni, hogy a CCA alapján megalkotott (szükség)rendeletek jogforrási hierarchiában való elhelyezését a kodifikátorok részben az 1998-as emberi jogi törvényre visszautalással oldották meg,70 ami azt jelenti, hogy a (szükség)rendeletek másodlagos jogforrásnak minősülnek, amelyek - amennyiben tartalmuk az EJEE-vel ütközik - bíróság által megsemmisíthetók. Ez a lehetőség elsősorban nem az önmagukban korlátozott (harmincnapos) időbeli hatállyal bíró (szükség)-rendeletek, hanem az azok felhatalmazása alapján készült egyéb intézkedések miatt bír(na) kiemelt jelentőséggel. Tekintettel arra, hogy a CCA-t a gyakorlatban még nem alkalmazták, bírósági ítéletekben csak elméleti szinten, hatályos jogszabályként hivatkozzák.

64 CCA 24. $\$(2)$ bekezdés.

65 CCA 24. $\$$ (3) bekezdés.

66 CCA 24. \$(4) bekezdés.

67 Lásd a CCA tervezetéhez füzött miniszteri indokolást.

68 Fontos adalék, hogy eredetileg a brit alkotmány részét képező alapvető törvények korlátozhatatlanságát tervezték rögzíteni, de végül csak a legfontosabb elemek tételes felsorolása maradt a szövegben.

$69 \mathrm{Az}$ emberi jogi törvény tartalmára és a legfontosabb esetjogra lásd: www.equalityhumanrights.com/en/ human-rights/human-rights-act és www.equalityhumanrights.com/sites/default/files/human_rights_ human_lives_a_guide_for_public_authorities.pdf (Letöltve: 2020. november 25.).

70 Vö.: CCA 30. \$ (2) bekezdés. 
A 2020. évi járvány kezelésére a brit kormány külön szabályozás megalkotását kezdeményezte. A CVA egy speciális, a járványhoz kötött kivételes jogrendről szóló törvény, amely meghatározott ideig (alapesetben két évig) marad hatályban. Skóciában a járvánnyal kapcsolatban külön törvény elfogadására is ${ }^{72}$ sor került. ${ }^{73}$

A CVA rendelkezéseinek elsődleges célja a járvány kezelésének megkönnyítése és terjedésének lassítása, az állami szervek müködésének biztosítása és a gazdaság múködőképességének megőrzése. A CVA mindegyik célhoz kapcsolódóan - összhangban az Emberi Jogok Európai Egyezményével - lehetővé tesz bizonyos alapjogi korlátozásokat is. ${ }^{74} \mathrm{Az}$ előterjesztő ezeket az EJEE és az emberi jogokról szóló 1998-as törvény alapján még a törvényhozási vita során megvizsgálta (például hogy mennyiben arányos intézkedés a helyi önkormányzati választások egy évvel történő elhalasztása), ${ }^{75}$ és részletes magyarázatot adott az esetleges kollízió tekintetében. Vonatkozó bírói gyakorlat még a CVA vonatkozásában sem ismert.

\section{Egészségügyi vészhelyzet kezelése, koronavírus-járvány}

A brit kormánynak az 1930-as évek óta létezett olyan közegészségügyi törvénye, amely lehetővé tette az egyes fertőző betegségek elleni fellépést. ${ }^{76} \mathrm{~A}$ jelenleg hatályos közegészségügyi törvény, ${ }^{77}$ bár összegezte a területen lezajlott korábbi kodifikációs eredményeket, továbbra is csak a fertőző betegségek egy részével (kolera, pestis, sárgaláz) szembeni szabályozás megalkotását tette lehetôvé. A kormány - felismerve a jogalkotási szükséghelyzetet a közegészségügyi törvény 2008 -as módosításával ${ }^{78}$ lehetôvé tette, hogy a törvényt az újfajta kórokozók (például a SARS) elleni védekezésben is hasznosítani lehessen. ${ }^{79}$

2020-ban a koronavírus elleni védekezéshez szükséges első jogszabályokat ennek a modernizált közegészségügyi törvénynek a felhatalmazó rendelkezései alapján alkották meg.

71 A sunset-klauzula alkalmazására lásd még: https://commonslibrary.parliament.uk/social-policy/health/ coronavirus-bill-what-is-the-sunset-clause-provision (Letöltve: 2020. június 18.).

72 A CVA elfogadásához a skót parlament is hozzájárult 2020. március 24-én; a törvény 2020. március 25-én lépett hatályba.

$73 \mathrm{Ez}$ a Coronavirus (Scotland) Act 2020, amely 2020. április 6-án lépett hatályba. A törvényjavaslat indokolásának 3. pontja szerint CVAS célja a CVA pótlása és kiegészítése volt. Elérhetô: www.legislation.gov.uk/ asp/2020/7/notes/division/2 (Letöltve: 2020 . december 10.).

74 Ezeket részletesen lásd: https:/publications.parliament.uk/pa/bills/cbill/58-01/0122/Memorandum\%20 to $\% 20$ the $\% 20$ Joint $\% 20$ Committee\%200n\%20Human\%20Rights $\% 20-\% 20$ The $\% 20$ Coronavirus $\% 20$ Bill\%20 2020.pdf (Letöltve: 2020 . november 20.).

75 A választások elhalasztásáról lásd a törvényjavaslat indokolásának 450-489. pontját. Elérhető: https:// publications.parliament.uk/pa/bills/cbill/58-01/0122/en/20122enlp.pdf (Letöltve: 2020. november 20.).

76 Lásd még: https://woodfines.co.uk/2020/03/27/coronavirus-and-the-new-enforcement-powers (Letöltve: 2020. november 21.).

77 Public Health (Control of Diseases) Act 1984.

78 A módosításokat a Health and Social Care Act 2008 valósította meg.

79 Vö.: a Health and Social Care Act 2008 törvényjavaslatához készült indokolás 29-30. pont. Elérhető: www. legislation.gov.uk/ukpga/2008/14/notes/division/2 (Letöltve: 2020. november 21.). 
Az 1984-es közegészségügyi törvény hatálya azonban csak Angliára és Walesre terjed ki, Skóciára és Észak-Írországra külön törvények vonatkoznak. ${ }^{80} \mathrm{Ez}$ azt jelenti, hogy a koronavírussal kapcsolatos nemzeti szintű közegészségügyi intézkedéseket három különböző törvény felhatalmazása alapján kell(ett) megalkotni. ${ }^{81}$

A koronavírus a legújabb adatok szerint már 2019 decemberében megjelent az Egyesült Királyságban. ${ }^{82} \mathrm{Az}$ első koronavírussal kapcsolatos jogszabály, egy miniszteri rendelet ${ }^{83}$ 2020. február 10-én lépett hatályba a közegészségügyi törvényben biztosított felhatalmazás alapján. Ez csak Angliára és Walesre vonatkozott, és kötelezte a vizsgálat alá vont személyeket személyes információk (utazási adatok és tervek, megtörtént és tervezett találkozók) hatósággal történő megosztására, szűrővizsgálatok elvégzésére, a hatóság döntése alapján a karanténba vonulásra. A 2020. február 10. és március 20. közötti öt hét során a kormányzat jogalkotás helyett elsősorban kommunikációs eszközökkel próbálta a lakosságot önkorlátozásokra buzdítani ${ }^{84} \mathrm{~A}$ tanácsok, iránymutatások nagy része országrészenként eltérő volt.

A betegek számának folyamatos növekedését látva a brit kormány megvizsgálta a szükségállapot bevezetésének lehetőségét, és végül a CCA élesítése helyett egy kifejezetten a koronavírussal kapcsolatos helyzet kezelésére vonatkozó szükségállapoti törvény megalkotása mellett döntött, ez a CVA. Bár a törvény hatálya az Egyesült Királyság egész területére kiterjed, Angliában (és részben Walesben) a védekezést elsősorban az 1984-es közegészségügyi törvényben, míg Skóciában előbb a CVA-ban, majd a CVAS-ban biztosított felhatalmazás alapján kezelték. ${ }^{85}$ Észak-Írországban a védekezéshez szükséges felhatalmazást a helyben hatályos közegészségügyi törvény adta meg. ${ }^{86}$ Magát a CVA-t elsősorban a járvány közegészségügyi törvény alapján nem kezelhető hatásai elleni küzdelemre

80 Lásd: Public Health (Scotland) Act 2008 és Public Health (Northern Ireland) Act 1967, ezek ismertetésére azonban terjedelmi okok miatt itt nincs lehetőség.

81 Az egy országon belüli négy különböző védekezési módszer azonban csak részben köszönhetô az eltérô törvényi keretszabályozásnak, az okok inkább az egyes országrészeknek biztosított autonómiában (devolved administration) keresendők, amely alapján az egészségügyi intézkedések döntő többsége az egyes országrészek hatáskörébe került.

$82 \mathrm{Az}$ első koronavírusos halálesetre lásd: www.bbc.com/news/health-52589449 (Letöltve: 2020. november 19.) és https://metro.co.uk/2020/09/09/grandad-84-first-to-die-of-coronavirus-in-uk-fell-ill-two-weeks-beforechristmas-13244673 (Letöltve: 2020. november 19.).

83 The Health Protection (Coronavirus) Regulations 2020 (SI 2020/129).

84 Lásd: www.bbc.com/news/uk-51857856 (Letöltve: 2020. november 22.), www.bbc.com/news/uk-51917562 (Letöltve: 2020.11.20.) és www.bbc.com/news/uk-51952314 (Letöltve: 2020. november 22.).

85 Vö. például: The Health Protection (Coronavirus) (Restrictions) (Scotland) Regulations 2020, hatályba lépett: 2020.03.26.

86 Vö.: The Health Protection (Coronavirus, Restrictions) Regulations (Northern Ireland) 2020, hatályba lépett: 2020.03.28. 
használták (az egyes országrészekben), így például a bérletek felmondás elleni védelméhez szükséges szabályozás megalkotásához..$^{87}$

Tekintettel arra, hogy a CVA a koronavírus elleni küzdelem legmagasabb szintú jogszabálya, röviden ismertetni kell a megalkotásának célját és szerkezetét.

\subsection{A brit koronavírus-törvény}

A gyorsított eljárással elfogadott CVA az általános szükséghelyzeti szabályozáshoz (CCA) képest egy különös jogi rezsim, csak az adott vírusjárvány kormányzati kezelését kívánja megkönnyíteni, tehát nem célja a végrehajtó hatalom hatásköreinek általános bővítése. Ennek megfelelően a CVA hatálya korlátozott: alapesetben az elfogadástól számított 2 év, amely fél évvel csökkenthetô vagy fél évvel növelhető. ${ }^{88} \mathrm{~A}$ CVA egyik legfontosabb újítása ez a feltételes korlátozott hatály, amely lehetővé teszi a törvény egyes rendelkezéseinek hosszabb ideig történő hatályban tartását (vagyis a járvány által okozott helyzetek rugalmas, proaktív kezelését). ${ }^{89}$

A CVA-t a koronavírus-járvány elleni védekezés generális keretjogszabályaként alkották meg. Szabályai számos, az EJEE-ben rögzített jog korlátozását teszik lehetôvé (lásd fentebb). Ezenbelül a törvény a társadalom múködése szempontjából kiemelt fontosságú szolgáltatások, mint a kommunikáció, médiaszabályozás, gazdaság és közlekedés területén több korlátozási lehetőséget is biztosít a kormány számára.

A potenciálisan fertőző személyekkel kapcsolatos hatáskörök: ${ }^{\circ}$ a törvény biztosítja az Egyesült Királyság egyes országrészeinek kormányai részére, hogy az adott országot „vírusátadás-ellenőrzési időszakba" helyezzék. Ilyenkor a közegészségügyi tisztviselők előírhatják azon személyek elkülönítését, akiknek tesztje víruspozitív (vagy nem egyértelmû), vagy akik megítélésük szerint „potenciálisan fertőzők”. A bevándorlási tisztviselők és a rendőrség korlátozottabb hatáskörrel rendelkeznek azon személyek mozgásának korlátozására, akiknél a betegség gyanúja felmerül. Aki a törvény elöirásait megsérti, pénzbírsággal büntetendő.

A nyilvános összejövetelekre és helyiségekre vonatkozó hatáskörök: ${ }^{91}$ a törvény lehetővé teszi a miniszter számára az összejövetelek, rendezvények korlátozását vagy betiltását, valamint a helyiségekbe való belépés korlátozását (a melléklet részletesen körülírja a hatáskör

87 Lásd például: The Coronavirus Act 2020 (Assured Tenancies and Assured Shorthold Tenancies, Extension of Notice Periods) (Amendment) (Wales) Regulations 2020 (hatályos: 2020. 07. 24-től), illetve The Coronavirus Act 2020 (Residential Tenancies: Protection from Eviction) (Amendment) (England) Regulations 2020 (hatályos: 2020. 08. 28-tól) és The Business Tenancies (Coronavirus) (Restriction on Forfeiture: Relevant Period) (Northern Ireland) Regulations 2020 (hatályos: 2020. 06. 29-től).

88 Hasonlóan érvel a törvényjavaslat indokolása is a 173-175. pontban. Elérhető: https://publications.parliament. uk/pa/bills/cbill/58-01/0122/en/20122enlp.pdf (Letöltve: 2020. március 23.).

89 A 2 éves periódus látszólag mérsékelt, a korábbi, terrorizmus visszaszorításával kapcsolatos törvények 5 éves hatályt is ismertek. Vö.: https://commonslibrary.parliament.uk/social-policy/health/coronavirus-bill-whatis-the-sunset-clause-provision (Letöltve: 2020. március 23.).

90 CVA 51. \$ és 21 . melléklet.

91 CVA 50. \$ és 22. melléklet. 
terjedelmét). A miniszter csak akkor élhet ezzel a felhatalmazással, ha hivatalosan bejelentették, hogy a vírus „súlyos és közvetlen fenyegetést jelent” a közegészségügyre, és hogy a hatáskörök felhasználása hozzájárul a vírus terjedésének ellenőrzéséhez, vagy megkönnyíti az orvosi/sürgősségi források megfelelő felhasználását. Aki a törvényt megsérti, büncselekményt követ el, és pénzbírsággal büntetendő.

Oktatási intézmények és gyermekgondozók bezárásával kapcsolatos hatáskörök:92 a törvény felhatalmazza a minisztereket, hogy előírják az iskola vagy a regisztrált gyermekgondozó ideiglenes bezárását. Ha egy miniszter ilyen iránymutatást adna, az intézménynek észszerú lépéseket kell tennie annak megakadályozása érdekében, hogy az érintettek meghatározott ideig ezekre a helyekre belépjenek. A miniszter pontosabb utasításokat adhat a helyiségek egyes részeire vagy az érintettekre vonatkozóan is. A felhatalmazó rendelkezések alkalmazása előtt a jogalkotónak konzultálnia kell a közegészségügyi tisztviselőkkel.

A bérlők védelmével kapcsolatos intézkedések:93 lakóingatlanok esetében védelem a kilakoltatásoktól (a törvényes felmondási időt két hónapról három hónapra hosszabbították meg). Az üzleti bérleti díjak esetében védelem a bérlemény elkobzása ellen (ideiglenesen korlátozták a visszavétel lehetőségét a bérleti díj megfizetésének elmaradása esetén).

Élelmiszer-ellátás: ${ }^{94}$ a törvény - az élelmiszer-ellátási zavarok elkerülése, illetve kezelése érdekében - felhatalmazza a kormányt, hogy az élelmiszer-szállítókat és a kiskereskedőket kötelezze az élelmiszer-ellátási láncokkal kapcsolatos információik átadására.

Szakemberhiányból adódó problémák kezelése egyes nemzetbiztonsági területeken:95 az egyik kritikus terület a vizsgálatokról szóló törvény (Investigatory Act 2016 - a továbbiakban: IPA) alkalmazása, ugyanis ez a törvény teszi lehetôvé a nyomozati hatáskörök hírszerző és bûnüldöző szervek által történő felhasználását, amennyiben azok rendelkeznek az IPA alapján kibocsátott paranccsal (végzéssel). A vizsgálati jogkör alapján kiadott végzéseket az államtitkárnak és a 15 igazságügyi biztos egyikének kell aláírnia. Mivel a járvány a biztosok hosszabb időre történő kiesését eredményezheti, a törvény lehetôvé teszi további - ideiglenes - bírói biztosok kinevezését és a kinevezési folyamat módosítását. Az igazságügyi biztosoknak az elfogatóparancsot általában visszamenőleges hatállyal kell jóváhagyniuk annak meghozatalától számított három napon belül. A biztosokra nehezedő nyomás enyhítése érdekében a törvény lehetővé teszi ennek az időszaknak legfeljebb 12 napra történő emelését. A végzések általában maximum öt napig érvényesek. A törvényjavaslat ezt az időszakot legfeljebb 12 napra meghosszabbítja.

A CVA lehetôvé teszi továbbá, hogy a kormány az ujjlenyomatok és a DNS-profilok megőrzésének idejét hat hónapra meghosszabbítsa, ha az államtitkár úgy ítéli meg, hogy a koronavírus káros hatással van vagy valószínúleg káros hatással lesz azokra, akik a nemzetbiz-

92 CVA 37-38. \$ és 16-17. melléklet.

93 CVA 81-83. § és 29. melléklet.

94 CVA 25-29. \$.

95 CVA 22-24. és 50. \$. 
tonsági döntéseket meghozzák, és a nemzetbiztonság érdekében szükséges az ujjlenyomatok vagy a DNS-profilok megőrzése.

A törvény felhatalmazást ad a kikötők múködésének felfüggesztésére, ha a határőrség állományának csökkenése miatt nincs elegendő erőforrás a határ biztosításához. A kikötői mûveletek felfüggesztésével kapcsolatos kezdeti döntéseket a határőrség tisztviselője is meghozhatja, azonban a több mint 12 órás felfüggesztés esetében a miniszter dönt.

A korlátozásokon túlmenően a CVA célja a járvány kezelésének megkönnyítése. ${ }^{96}$ Ennek érdekében

- lehetôvé teszi az elérhető egészségügyi és szociális gondozói munkaerő létszámának növelését a már nyugdíjba vonult szakemberek, illetve a most egyetemre járó hallgatók bevonásával;

- lehetôvé teszi az első vonalban küzdő személyzetre háruló terhek csökkentését az adminisztratív terhek csökkentése, az intézkedési szabadság növelése, például az ellátásra szorulók kategorizálása révén;

- lehetôvé teszi a vírus terjedésének feltartóztatását, illetve lassítását a társas érintkezések számának csökkentésével és a karanténszabályok erősítésével (ezek közé tartozik többek között a soron következő választások elhalasztása is); ${ }^{97}$

- lehetôvé teszi a halálozások adminisztrációjának gyorsítását, továbbá a holttestek méltóságának megơrzéséhez szükséges intézkedések megtételét;

- bővíti a törvényes betegszabadság igénylésére jogosultak körét.

\subsection{Az ország lezárása (national lockdown és local lockdown)}

A kormány még a CVA elfogadása elôtt megkezdte az ország lezárását, országrészenként különböző, de általában a helyi közegészségügyi törvények felhatalmazása alapján kiadott rendeletekkel. A lezárásokhoz kapcsolódva fontos megjegyezni, hogy a járvány súlyosságától függően országon belül külön szabályozási enklávék is létrejöhettek. A helyi lezárások (local lockdowns) modelljét Angliában dolgozták ki, de más országrészekben (például Walesben ${ }^{98}$ és Skóciában ${ }^{99}$ ) is alkalmazták. Ezeket a rendeleteket szintén a közegészségügyi törvény alapján bocsátotta ki a központi (vagy az országrészi) kormány. A helyi lezárási jogi rezsimeket 2020. július 4. és 2020. október 14. között több településre, övezetre, régióra alkalmazták (először

96 Lásd bővebben a kormányzati honlapot: www.gov.uk/government/publications/coronavirus-bill-what-itwill-do/what-the-coronavirus-bill-will-do (Letöltve: 2020. március 23.).

97 A választások elhalasztásának ugyancsak járványügyi oka van, erre legutóbb 2001-ben került sor, szintén járványügyi okok miatt (száj- és körömfájásjárvány). Lásd bővebben: www.bbc.com/news/uk-politics-51876269 (Letöltve: 2020. március 23.).

98 Vö.: The Health Protection (Coronavirus Restrictions) (No. 2) (Wales) (Amendment) (No. 8) (Caerphilly) Regulations 2020, hatályos: 2020. 09. 08-tól, illetve The Health Protection (Coronavirus Restrictions) (No. 2) (Wales) (Amendment) (No. 10) (Rhondda Cynon Taf) Regulations 2020, hatálybe lépett: 2020. 09. 17.

99 Vö.: The Health Protection (Coronavirus, Restrictions) (Aberdeen City) Regulations 2020, hatályba lépett: 2020. 08. 05 . 
Leicesterre [Leicestershire], ${ }^{100}$ később más településekre [például: Luton, Bedfordshire vagy Blackburn, Darwen és Luton, Lancashire ${ }^{101}$ is).

A helyi lezárást - analógiával élve - nemcsak településekre, hanem akár jogi személyekre is ki lehetett szabni. Így akár egy adott céget is helyi lezárás alá lehetett vonni, ha ez közegészségügyi szempontból fontosnak számított (lásd például a Greencore Food to Go Ltd.-esetet). ${ }^{102}$

A központi kormányzat által közegészségügyi szempontból elrendelt helyi lezárásoktól el kell határolni a központi kormányzat által a helyi önkormányzatok számára biztosított jogalkotási felhatalmazást. Ez egyrészt a bezárások elrendelését, másrészt azok kikényszerítését tette lehetővé. Ezt még 2020 júliusában egy, a közegészségügyi törvény felhatalmazása alapján kibocsátott rendeletben adta meg az angliai helyi önkormányzatok számára az egészségügyi miniszter. ${ }^{103} \mathrm{~A}$ helyi önkormányzat által elrendelt lezárásokról minden esetben értesíteni kell az egészségügyi minisztert, és valamennyi, helyben meghozott intézkedést legkésőbb hétnaponta felül kell vizsgálni. ${ }^{104} \mathrm{Az}$ angliai példával később más országrészek kormányzata (Skócia, ${ }^{105} W^{10}$ les ${ }^{106}$ és Észak-Írország ${ }^{107}$ ) is élt.

Nagyjából egy hónapos teljes zárást követően 2020. április végétől egy több hónapos, lassú, fokozatos nyitás kezdődött, amelyet az egyes országrészek elsősorban a lezárást elrendelő jogszabályok többszöri módosítása révén értek el. A fokozatos enyhülés tavasztól kora őszig tartott, országrészenként eltérő ütemben.

2020. nyár végétől, ahogy az esetszám újra emelkedni kezdett, a központi kormány és az országrészek kormányzata is a korlátozások újabb bevezetése mellett döntött. Az ősz folyamán a helyi szintû́ korlátozásokat a települések többfokozatú besorolása váltotta fel. Angliában három-, Skóciában ötfokozatú skála bevezetése mellett döntöttek. ${ }^{108} \mathrm{~A}$ skálát végül

100 Vö.: az egészségvédelemről (koronavírus, korlátozások) (Leicester) szóló 2020. évi rendelet (SI 2020/685), hatályba lépett: 2020. 07. 04.

101 Vö.: The Health Protection (Coronavirus, Restrictions) (Blackburn with Darwen and Luton) Regulations 2020 (SI 2020/800), hatályba lépett: 2020. 07. 25. és The Health Protection (Coronavirus, Restrictions) (Blackburn with Darwen and Luton) Regulations 2020 (SI 2020/800), hatályba lépett: 2020. 07. 25.

102 Vö.: The Health Protection (Coronavirus, Restrictions) (Greencore) Regulations 2020 (SI 2020/921), hatályba lépett: 2020. 08. 29.

103 Vö.: The Health Protection (Coronavirus, Restrictions) (England) (No. 3) Regulations 2020 (SI 2020/750), hatályba lépett: 2020. 07.18.

104 The Health Protection (Coronavirus, Restrictions) (England) (No. 3) Regulations 2020 (SI 2020/750) 2. \$ (1) bekezdés és $12 . \$(1)-(2)$ bekezdés.

105 The Health Protection (Coronavirus Restrictions) (Functions of Local Authorities) (Wales) Regulations 2020, hatályos: 2020. 09. 14-től; The Health Protection (Coronavirus, Restrictions) (Directions by Local Authorities) (Scotland) Regulations 2020, hatályba lépett: 2020. 08. 28.

106 The Health Protection (Coronavirus Restrictions) (Functions of Local Authorities) (Wales) Regulations 2020, hatályba lépett: 2020. 09. 14.

107 The Health Protection (Coronavirus, Restrictions) (No. 2) (Amendment No. 8) Regulations (Northern Ireland) 2020, hatályba lépett: 2020. 10. 05.

108 Lásd még: www.instituteforgovernment.org.uk/blog/three-tiers-coronavirus-rebrand (Letöltve: 2020. november 25.). 
októberben részleges, novemberben országos lezárás váltotta fel, egyelőre december elejéig. ${ }^{109}$ Decemberben Angliában egy negyedik lezárási fokozatot is bevezettek, ${ }^{110}$ Skóciában továbbra is maradt az ötfokozatú skála. ${ }^{111}$

\section{A különleges jogrenddel és a járványügyi veszélyhelyzet kihirdetésével kapcsolatos tapasztalatok, jogviták}

Fentebb már említettük, hogy sem a CCA-val, sem a CVA-val kapcsolatban nincs még releváns bírói gyakorlat. Az előbbi esetben ennek legfóbb oka, hogy a törvénynek a jelen kötet szempontjából releváns második részét a gyakorlatban egyelöre még nem alkalmazták. Az utóbbi esetben a törvény megalkotása óta eltelt több mint fél évben egyértelmúvé vált, hogy a CVA elsődleges célja nem a kormány hatásköreinek bővítése, hanem a járvány kezelését megkönnyítő hatáskörük átmeneti biztosítása a végrehajtó hatalom számára. Másrészt a CVA gyakorlati alkalmazása megmutatta, hogy a törvényt elsősorban a közegészségügyi törvények mellett, kisegítő jelleggel használják.

Mindez azonban nem jelenti azt, hogy a koronavírus-járvány mentes lett volna a jogvitáktól. A viták három legfontosabb iránya:

- a védekezést és az alapjog-korlátozásokat elsősorban lehetővé tevő közegészségügyi törvénnyel és annak felhatalmazó rendelkezéseivel kapcsolatos problémák;

- a járvánnyal kapcsolatos lezárások szükségessége és arányossága (az EJEE rendelkezéseinek értelmezése);

— a járványból adódó jövőbeli feladatok és kötelezettségek alkotmányossága (például: egy esetleges védőoltás önkéntes vagy kötelező jellege).

A fenti problémák messzire vezetnek, hiszen a kérdések csak látszólag szólnak a felhatalmazások jogszerúségéről, valójában a békeidőben rendkívülinek számító korlátozások terjedelmét, az ezzel kapcsolatos döntések meghozatalára feljogosítottak személyét és eljárását érintik. 2020-ban tulajdonképpen a több mint hét évtizedes háborúmentes időszak legjelentősebb korlátozásait kényszerítette ki a kormányzat rövid pár hét alatt. Ennek nyomán szokások, életutak változtak meg, illetve szúkültek (eltérő mértékben) az egyének és egyes csoportok megélhetési lehetőségei. A kormányzat által bevezetett szabályok egyes esetekben

109 Az egyes országrészek eltérő szabályait bemutató áttekintő táblázatokat lásd: www.instituteforgovernment. org.uk/explainers/coronavirus-lockdown-rules-four-nations-uk (Letöltve: 2020. november 25.). A 2020. december elején bevezetett háromfokozatú angol skálára lásd: www.bbc.com/news/explainers-52530518 (2020. december 2.).

110 Lásd: www.theguardian.com/uk-news/2020/dec/19/Covid-tier-4-what-are-the-new-restrictions-for-londonand-south-east-england (2020. december 19.).

111 Lásd:www.bbc.com/news/explainers-52530518 és www.bbc.com/news/uk-scotland-55318075 (Letöltve: 2020. december 19.). 
egyéni életeket tettek ki közvetlen veszélynek közérdekre vagy mások jogos érdekére (például busz- vagy villamosvezetők a tömegközlekedésben) hivatkozással, esetleg több generáció alatt társadalmi normává vált magatartási szabályokat írtak felül.

Mindezekre tekintettel a változások mértéke, arányossága és szükségszerúsége értelemszerúen mélyreható jogi vizsgálatot igényel. Ugyanakkor azt is mérlegelni szükséges, hogy az EJEE által lehetôvé tett alapjog-korlátozások, illetve a közegészségügyi törvény által a járványok kezelésére biztosított felhatalmazások célhoz kötöttek, és az, hogy széles körú alkalmazásukat az elfogadásuk óta eltelt évtizedek alatt sikerült elkerülni, vagyis hogy jelenleg hiányzik a jogalkalmazói tapasztalat, csakis a véletlennek volt köszönhető.

A fenti kérdéseket egy vállalkozó által a kormány ellen indított kereset összegzi. ${ }^{112} \mathrm{~A}$ per 2020 júliusa óta több fórumot is megjárt, jelenleg (2020. 12. 15.) is folyamatban van.

A precedensértékú pertôl eltekintve az országos szintú lezárás alapjog-korlátozó hatása, illetve arányossága és szükségszerüsége, valamint a járvány elleni védőoltás önkéntessége vagy kötelező jellege már 2020 tavaszától elméleti vitákat generált egyes internetes jogi fórumokon. A különböző értékelések felhívták a figyelmet többek között az EJEE-ben foglalt egyes alapjogok - mint például az élethez való jog - kapcsán az államra háruló pozitív védelmi kötelezettségre, valamint arra is, hogy a járvány elleni védekezés elmulasztása - tekintettel az idősek és az egyes etnikai kisebbségek átlagon felüli fertőzöttségi rátájára - valószínúleg alkalmas lenne az EJEE 14. cikkében foglaltak (megkülönböztetés tilalma) állam általi megsértésének megállapítására. ${ }^{113}$

Olyan jogi vélemény is akad, amely az arányosság oldaláról közelítve - a brit bírói gyakorlat elemzésével - úgy ítéli meg, hogy az országos lezárások túlterjeszkedtek a jogszabályi kereteken (vagyis aránytalanok). ${ }^{114}$ Végül olyan véleményt is megfogalmaztak, amely szerint a kormány járvánnyal kapcsolatos intézkedései mind az EJEE, mind a brit jogszabályi környezet alapján arányosak és szükségesek voltak. ${ }^{115}$

A lezárások és az emberi jogok kollíziójának kérdésében a brit kormány részletesen is kifejtette álláspontját, amikor 2020 őszén részletes írásos beszámolót nyújtott be a parlament alsóháza emberi jogi bizottságának. ${ }^{116}$

112 A Simon Dolan-ügyben hozott elsőfokú ítélet: www.bailii.org/cgi-bin/format.cgi?doc=/ew/cases/EWHC/ Admin/2020/1786.htm (Letöltve: 2020. november 23.), valamint https://bdaily.co.uk/articles/2020/10/22/speakerintervenes-in-simon-dolans-legal-fight-against-lockdown (Letöltve: 2020. november 23.), https://bdaily.co.uk/ articles/2020/12/o1/simon-dolan-bid-to-take-fight-to-supreme-court (Letöltve: 2020. december 15.).

113 Elérhetô: https://ukhumanrightsblog.com/2020/04/30/the-coronavirus-lockdown-does-not-breach-humanrights-part-one-leo-davidson (Letöltve: 2020 . november 23.).

114 Elérhetô: https://ukhumanrightsblog.com/2020/04/21/a-disproportionate-interference-the-coronavirusregulations-and-the-echr-francis-hoar (Letöltve: 2020. november 23.).

115 Elérhető: https://ukhumanrightsblog.com/2020/05/11/leviathan-challenged-the-lockdown-is-compliant-withhuman-rights-law-part-two (Letöltve: 2020 . november 23.).

116 Bővebben lásd: https://publications.parliament.uk/pa/jt5801/jtselect/jtrights/265/26502.htm (Letöltve: 2020. november 23.). Az emberi jogi vonatkozásokra lásd még a Velencei Bizottság két jelentését: Venice Commission $2020 \mathrm{a}, 2020 \mathrm{~b}$. 
A folyamatban lévő, fentebb említett per kimenetele már csak e konkuráló jogértelmezések megerősítése vagy elvetése miatt is kiemelkedően fontos következménnyel járhat.

Végül - a jövőbe tekintve - itt kell megemlíteni a vakcináció kérdéskörét is, hiszen az eddigi tudományos vélemények alapján nem zárható ki a világjárványok ismétlődése. Vajon egy ilyen, teljes társadalmat veszélyeztetô betegség elleni oltás a brit esetjog és jogszabályok alapján lehet-e kötelező, és ha igen, maga a kötelezés arányos intézkedésnek tekinthető-e?"17

A kormányzat egyelőre az önkéntes oltást preferálja, ${ }^{118}$ de figyelembe kell venni, hogy a jogalkotó nemcsak közvetlen, de közvetett szabályozási módszerrel is élhet. ${ }^{119}$ Sőt, akár a vállalkozások is kikényszeríthetik egyes esetekben (például egyes repülőutak ${ }^{120}$ vagy általában a légi közlekedés) az oltások kötelező felvételét.

A lezárások esetében jól nyomon követhető volt a jogalkotó szabályozói koncepciójának folyamatos változása, ezért könnyen elképzelhetô, hogy ebben a kérdésben is sor kerül majd több különböző jogi álláspont kifejtésére, illetve ütköztetésére, és a kormány véleménye - a társadalmi, valamint a gazdasági érdekek függvényében - a későbbiekben akár meg is változhat.

\section{6. Összegzés}

A fentiekben a kivételes hatalom brit szabályozását mutattuk be. Ennek során egyrészt az általános szabályokat, a jogforrási hierarchiát, az anyagi és alaki szabályokat elemeztük, másrészt pedig e szabályrendszer egyetlen speciális helyzetben, a 2020-as koronavírus-járvány során történt alkalmazását vontuk vizsgálat alá.

Látható volt, hogy a polgári vészhelyzeti törvény hosszú, több évtizedes jogfejlődés eredményeképpen született meg, és bár a megalkotása óta eltelt másfél évtized alatt nem alkalmazták, kifinomult kodifikációs megoldásaival már csak azért is érdemes megismerkedni, mert nem egy hétköznapi jogszabályról, hanem egy speciális, a brit történeti alkotmány részét képező törvényről van szó. A CCA a kivételes hatalom gyakorlását több előfeltétel fennállásához köti, és ezek bekövetkezése esetén is korlátokat állít a kivételes hatalom birtokosa elé. A korlátok többfélék. Egy részük a (szükség)rendelet megalkotója számára próbálja csoportosítani a lehetséges jogalkotási tárgyakat, másik részük a (szükség)rendelet érvényességi feltételeit rögzíti (kibocsátó személye, időbeli és tárgyi hatály korlátai, utólagos

117 Bővebben lásd: https://ukhumanrightsblog.com/2020/11/05/compulsory-vaccination-the-next-step-forCovid-19 (Letöltve: 2020. november 23.).

118 Elérhető: www.thesun.co.uk/news/13218179/matt-hancock-refuses-rule-out-Covid-vaccine-mandatory (Letöltve: 2020 . november 23.).

119 Például előírhatja, hogy egy meghatározott helyen tartózkodáshoz szükséges az oltás felvétele. Vö.: www. dailymail.co.uk/news/article-9003321/Restaurants-bars-cinemas-turn-customers-without-Covid-jab-away. html (Letöltve: 2020 . december 2.).

120 Vö.: www.telegraph.co.uk/news/2020/11/28/airlines-mull-compulsory-Covid-19-vaccinations-passengerssolution (Letöltve: 2020. december 2.), valamint www.bbc.com/news/world-australia-55048438 (Letöltve: 2020. december 2.). 
parlamenti kontroll, kizárt jogalkotási tárgyak). A korlátok harmadik csoportja pedig egyéb eljárási kötelezettségeket ír elő a jogalkotó számára, de oly módon, hogy ezek megvalósítása a jogforrás tartalmát is érinti (feltételes konzultációs kötelezettség, koordinátorok kinevezésével kapcsolatos feladatok).

A (szülkség)rendelet megalkotója a CCA által lehetővé tett körben és mértékig a büntetôhatalom gyakorlására is jogosulttá válik, azonban büntetőjogi vagy szabálysértési tényállást csak a törvény által elôirt körben konstituálhat, pénzbírság kiszabását pedig csak a törvényben meghatározott mértékig írhatja eló.

Bár a CCA-t kifejezetten a kormány jogköreinek a szükségállapot kezeléséhez szükséges mértékben történő bővítése céljából alkották meg, a koronavírus-járvány kezelésére a brit parlament végül egy külön törvény, a koronavírus-törvény (CVA) megalkotása mellett döntött. Ezt részben a járvány súlyos következményeire (emberek tömeges megbetegedése, munkából való kiesése, munkanélkülivé válása, halála) való felkészüléssel, részben pedig a járvány időbeli elhúzódásával indokolták. Ez utóbbi helyzet kezelését a korlátozott feltételes hatály (egy kétéves időbeli hatályt előíró sunset-clause) beiktatásával kívánták megoldani.

Az első jogalkotói lépések megtétele azonban még a CVA megalkotása előtt szükségessé vált, így adta magát a közegészségügyi törvény által biztosított felhatalmazások alkalmazása. A közegészségügyi törvény nemcsak a gyors intézkedést, de a helyben legjobbnak tủnő szabályok bevezetését is lehetővé tette, ezért már 2020 tavaszán több országrészben is a járvány elleni jogalkotás elsődleges keretszabályává vált. A CVA-ban biztosított jogköröket végül mindeddig (2020. december 1-ig) csak részben kellett „élesíteni”.

A járvány elleni küzdelem során hozott korlátozó intézkedések arányossága és szükségessége rövid időn belül jogi természetú vitákat generált, kezdetben elméleti síkon, majd a gyakorlatban, bírósági kereset formájában is. A harmadik, az idő előrehaladtával egyre aktuálisabbá váló kérdéskör a védőoltás önkéntes vagy kötelező jellegének szabályozása körül alakul ki.

Fontos továbbá azt is megemlíteni, hogy a koronavírus-járvány elleni védekezés különböző koncepcióinak országrészenként eltérő eredményessége képes befolyásolni az egységes, illetve megosztott nemzeti szuverenitásról az uniós kilépés nyomán megélénkült (jogi) vitákat, már csak amiatt is, mert a helyi egészségüggyel kapcsolatos hatáskörök többsége már évekkel ezelőtt az egyes országrészek kormányzatának hatáskörébe került.

Végezetül röviden szólni kell a brit és magyar szabályozás hasonlóságairól és különbségeiről, valamint arról is, vajon a brit modell, illetve a koronavírus elleni védekezés tartogat-e tanulságokat a magyar jogalkotó számára.

Láthattuk, hogy a kivételes hatalom szabályozásának gyökerei mindkét államban több évszázadra nyúlnak vissza, ráadásul a jelenlegi szabályozás mindkét esetben a polgári hatóságok kezébe helyezi a rendkívüli helyzet menedzselését. Eltérőek azonban a szabályozási szintek és az esetkörök. Míg Magyarországon az elsődleges jogforrás e szabályozási tárgykör esetében is az Alaptörvény, amely több esetkört is részletesen elkülönít, addig az Egyesült Királyságban a kivételes hatalom - egy, a történeti alkotmány részét képező - külön tör- 
vényben került szabályozásra, amely csak egy esetkört ismer. A szabályozási aszimmetria a jogforrási hierarchia más szintjein is tetten érhető: Magyarországon a részletszabályokat törvények és ezek felhatalmazása alapján rendeletek, míg az Egyesült Királyságban rendeletek tartalmazzák.

Az általános szabályozás összehasonlítása mellett röviden a koronavírus-járványhoz kapcsolódóan megalkotott joganyagról is szólni szükséges. Az Egyesült Királyságban egy speciálisan a helyzet kezelésére szolgáló, meghatározott ideig (két évig) hatályos törvény megalkotására került sor, ám a védekezés nagy részét a közegészségügyi törvény felhatalmazása alapján kibocsátott rendeletekkel végezték el. Magyarországon ezzel szemben több törvény megalkotására is sor került, de a védekezés alapjául szolgáló joganyagot részben alkotmányi, részben törvényi felhatalmazások alapján bocsátották ki.

A védekezési stratégiák természetesen eltérőek voltak a két országban, de ennek egyik fó oka (a fertőzöttségi adatokban meglévő különbségek mellett) az eltérő közigazgatási szerkezetben keresendő. Bár elméletileg mindkét ország unitárius állam, az Egyesült Királyságban négy országrészi kormányzat múködik, és a helyi egészségügyi intézkedések a tartományi autonómia körébe tartoznak. Az eltérő közigazgatási szerkezetnek is köszönhető, hogy míg Magyarországon a járvány elleni védekezés a központosítás irányába hatott, addig az Egyesült Királyságban a kezdeti időszaktól eltekintve az intézkedések az országrészi kormányzatok szerepének folyamatos erősödésével jártak - igaz, e folyamat mögött ott feszült az uniós kilépés által újra felerősített szuverenitásvita is, amely a közeljövőben könnyen a Brit-szigetek uniójának felbomlását is magával hozhatja. Vagyis miközben Magyarországon a járvánnyal kapcsolatos védekezés elsődlegesen egy egészségügyi veszélyhelyzet jogi-politikai kezelését jelentette, addig az Egyesült Királyságban a koronavírus elleni küzdelem egyúttal az államközösség hatékony múködésének próbájaként is szolgált, és az egészségügyi veszélyhelyzet súlyos, az európai uniós tagság által korábban elfedett közjogi problémák megoldásával kapcsolódott (kapcsolódik) össze.

\section{Irodalomjegyzék}

Bowman, H. (1916) 'Martial Law and the English Constitution', Michigan Law Review, 15(2), 93-126. 0.

Clark, R. A. (2016) Business Continuity and the Pandemic Threat. Ely: IT Governance Publishing ConchA, Gy. (1885) Újkori alkotmányok II. (Anglia). 1. kiadás. Budapest: Magyar Tudományos Akadémia

Cotter, C. (1953) 'Constitutionalizing Emergency Powers: The British Experience', Stanford Law Review, 5(3), 382-417. o.

Csink, L. (2017) ‘Mikor legyen a jogrend különleges?', Iustum Aequum Salutare, 13(4), 7-16. o. 
EbuRn, M. (2017) Coordination of Federal, State and Local Disaster Management Arrangements in Australia. Lessons from the UK and the US [Online]. Elérhetô: www.jstor.org/stable/ resrepo4119 (Letöltve: 2020. december 6.)

FARKAS, Á., Kelemen, R. (szerk.) (2020) Szkülla és Kharübdisz között-Tanulmányok a különleges jogrend elméleti és pragmatikus kérdéseiról, valamint nemzetközi megoldásairól. 1. kiadás. Budapest: Magyar Katonai Jogi és Hadijogi Társaság

JAKAB, A., Till, Sz. (2019) 'A különleges jogrend' in Trócsányi, L., Schanda, B. (szerk.) Bevezetés az alkotmányjogba. Budapest: HVG-ORAC.

JÁnosi, F. (1867) Alkotmányok gyüjteménye I. (Anglia). 1. kiadás. Pest: Pfeiffer

KeLEMEN, R. (2019) 'Az Alaptörvény szükségállapot-szabályozásának kritikai áttekintése az egyes európai uniós tagállamok alkotmányainak figyelembevételével - Különös tekintettel a visegrádi államok alkotmányaira' in Bartkó, R. (szerk.) A terrorizmus elleni küzdelem aktuális kérdései a XXI. században. 1. kiadás. Budapest: Gondolat Kiadó

KojA, F. (2003) 'Állami szükségállapot és a szükségállapotra vonatkozó jog' in Takács, P. (szerk.) Államtan. 1. kiadás. Budapest: Szent István Társulat

RoSENFELd, M., SAJó, A. (szerk.) (2013) The Oxford Handbook of Comparative Constitutional Law. 1. kiadás. Oxford: Oxford University Press

SABJANics, I. (2014) 'Minősített időszakok az Alaptörvényen innen és azon túl' in Kovács, P. (szerk.) Religio et Constitutio. 1. kiadás. Budapest: Pázmány Press

TilL, Sz. (2019) 'Különleges jogrend' in Jakab, A., Fekete, B. (szerk.) Internetes Jogtudományi Enciklopédia [Online]. Elérhetó: https://ijoten.hu/uploads/kulonleges-jogrend.pdf (Letöltve: 2020. december 1.)

Tóтн, Á. (1967) 'A kivételes állapot intézményének kialakulása néhány burzsoá állam jogrendszerében', Acta Universitatis Szegediensis: Acta Juridica et Politica, 14(8), 3-19. o.

Venice Commission (2020a) Interim Report on the Measures Taken in the EU Member States as a Result of the Covid-19 Crisis and Their Impact on Democracy, the Rule of Law and Fundamental Rights (Opinion No. 995/2020) [Online]. Elérhető: www.venice.coe.int/webforms/ documents/default.aspx?pdffile $=\mathrm{CDL}-\mathrm{AD}$ (2020)o18-e (Letöltve: 2020 . december 15.)

Venice Commission (2020b) Respect for Democracy, Human Rights and the Rule of Law During States of Emergency: Reflections (Study No. 987/2020) [Online]. Elérhető: https://rm.coe.int/ respect-for-democracy-hu-man-rights-and-rule-of-law-during-states-of-e/16809e82co (Letöltve: 2020. december 15.) 